\title{
Mercury and stable isotope cycles in baleen plates are consistent with year-round feeding in two bowhead whale (Balaena mysticetus) populations
}

\author{
Corinne Pomerleau ${ }^{1}(1)$. Cory J. D. Matthews ${ }^{2} \cdot$ Charles Gobeil $^{3}$ - Gary A. Stern ${ }^{1} \cdot$ Steven H. Ferguson ${ }^{2}$. \\ Robie W. Macdonald ${ }^{1,4}$
}

Received: 13 October 2017 / Revised: 26 March 2018 / Accepted: 4 April 2018

(c) Springer-Verlag GmbH Germany, part of Springer Nature 2018

\begin{abstract}
Previous studies have demonstrated that the analysis of biogeochemical tracers along baleen can provide seasonal, annual, and longer term insights into whale movements, habitat use, diet, and ecosystem processes. We measured the mercury $(\mathrm{Hg})$ concentration and stable carbon $\left(\delta^{13} \mathrm{C}\right)$ and nitrogen $\left(\delta^{15} \mathrm{~N}\right)$ isotope compositions along baleen plates of bowhead whales (Balaena mysticetus) harvested between 1988 and 1996 from the Bering-Chukchi-Beaufort (BCB) and the Eastern CanadaWest Greenland (EC-WG) populations. These measurements were compared among individuals and between populations to assess seasonal cycling and to determine if bowhead whales forage year-round rather than fasting in winter. Individuals from the $\mathrm{BCB}$ population had synchronous cycles with higher $\mathrm{Hg}$ concentrations and lower $\delta^{13} \mathrm{C}$ values in summer and lower $\mathrm{Hg}$ concentrations and higher $\delta^{13} \mathrm{C}$ values in winter. $\mathrm{EC}-\mathrm{WG}$ individuals also had synchronized periodic variations with peak values in isotopic ratios during summer. These results reflect an annual cycle of seasonal migration between distinct food webs in both populations. Spring and fall feeding activity was indicated in the intra-annual $\mathrm{Hg}$ and $\delta^{13} \mathrm{C}$ cycles along the baleen plates of all whales in our study. These shorter periods, spanning about half the annual growth, have not been previously described in the baleen of these populations, and are consistent with separate foraging areas along the migration routes. The results of this study provide further support for year-round foraging in a species previously thought to fast during winter. Future monitoring of seasonal foraging patterns in baleen would help to determine whether bowhead whales alter their foraging patterns in response to shifts in zooplankton community availability, composition, and phenology.
\end{abstract}

Keywords Arctic $\cdot$ Baleen $\cdot$ Bowhead whale $\cdot$ Carbon $\cdot$ Mercury $\cdot$ Nitrogen $\cdot$ Stable isotopes $\cdot$ Time series

\section{Introduction}

The bowhead whale (Balaena mysticetus) is a large mysticete endemic to the Arctic Ocean and its marginal seas. There are two genetically and spatially distinct populations in

Corinne Pomerleau

corinne.pomerleau@umanitoba.ca

1 Centre for Earth and Observation Science, University of Manitoba, Winnipeg, Canada

2 Freshwater Institute, Fisheries and Oceans Canada, Winnipeg, Canada

3 Centre Eau Terre Environnement, Institut National de Recherche Scientifique, Québec, Canada

4 Institute of Ocean Sciences, Fisheries and Oceans Canada, Sidney, Canada
Canadian waters: the Bering-Chukchi-Beaufort population (BCB) in the Western Arctic and the Eastern Canada-West Greenland population (EC-WG) (Rugh et al. 2003) in the Eastern Arctic (Fig. 1). Both populations undertake long seasonal migrations across their ranges, in part constrained by the distribution of sea-ice, encountering various water masses and associated prey assemblages (Heide-Jørgensen et al. 2003; Ferguson et al. 2010; Pomerleau et al. 2012).

The BCB population overwinters in the Chukchi and the northern Bering Seas and spends the summer in the Alaskan and Canadian Beaufort Sea (Moore and Reeves 1993; Schell and Saupe 1993; Moore et al. 2010; Harwood et al. 2017). The EC-WG population overwinters in Hudson Strait, northern Hudson Bay, east of Baffin Island, and near the ice edge along West Greenland (Koski et al. 2006; HeideJørgensen et al. 2007; Ferguson et al. 2010). The summer range for the eastern bowhead population includes the fjords 


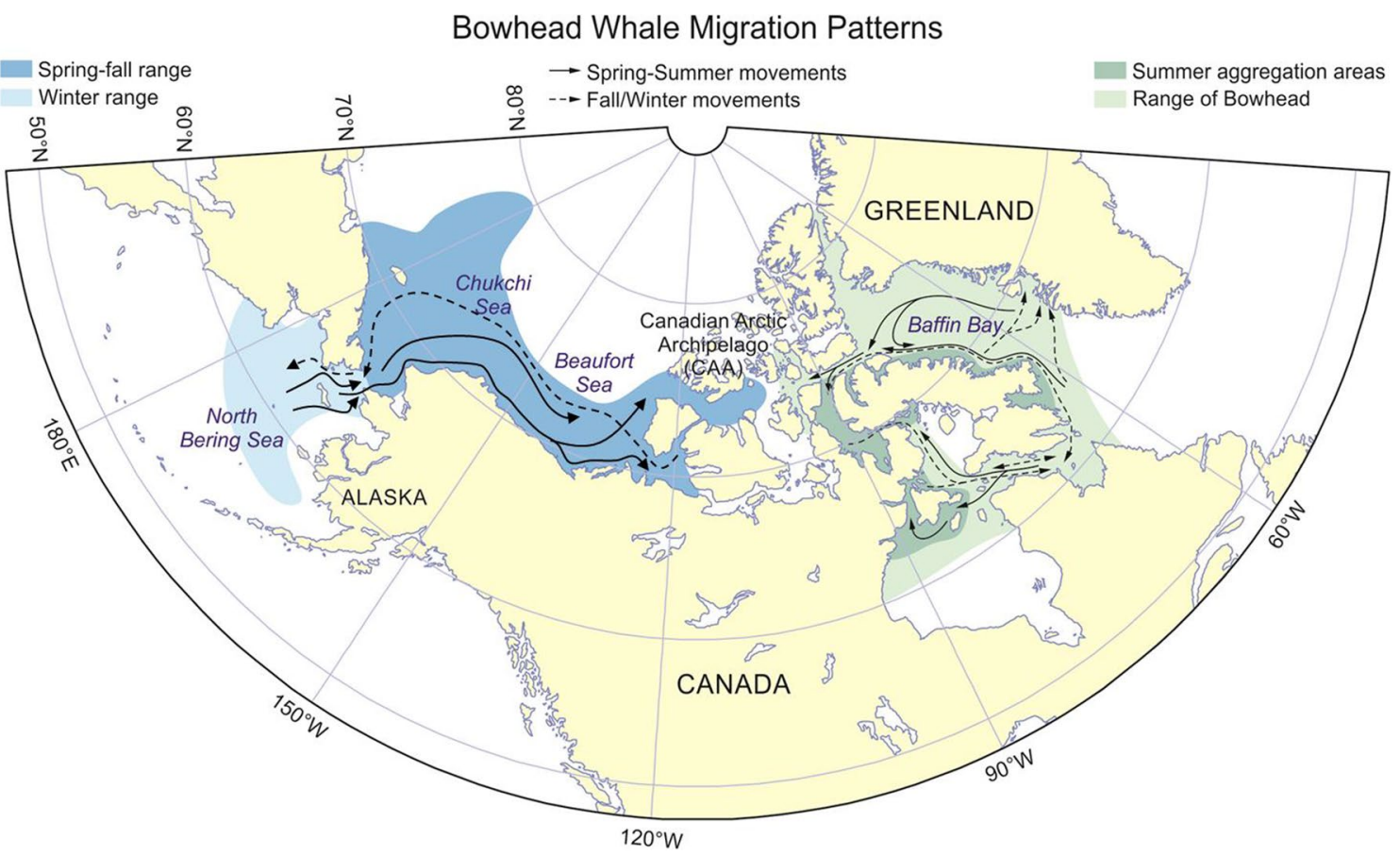

Fig. 1 Map showing the seasonal broad distribution ranges of bowhead whales (Balaena mysticetus) in the Eastern (green) and Western Arctic (blue). Plain black arrows indicate broad northward migration

and bays around Baffin Island, Hudson Bay, and Foxe Basin (Higdon and Ferguson 2010). Feeding on copepods (e.g., Calanus spp.), euphausiids and epibenthic invertebrates (Lowry 1993; Finley 2001; Lowry et al. 2004; Moore et al. 2010; Pomerleau et al. 2011a, 2012, 2014a) mainly occurs in the summer season (highest productivity) in both populations. Segments of the EC-WG population are also known to forage in early spring along the west coast of Greenland (Laidre et al. 2007) and early fall in Isabella Bay, Nunavut (Finley 1990, 2001).

Mysticete whales migrate from low-latitude regions where they mate, but little feeding is assumed to occur, to high latitudes where most feeding happens (Corkeron and Connor 1999). BCB whales have been observed feeding around Alaska during their westbound fall migration (Lowry et al. 2004) and to some extent in the Bering Sea during winter (Lee et al. 2005). Although it has generally been assumed for both populations that foraging is limited in winter (Lowry and Frost 1984; Finley 2001), Schell and Saupe (1993) proposed that significant foraging occurs year-round. Recent studies have shown that winter foraging occurs and may be important in the annual energy budget of bowhead whales (Citta et al. 2014; Matthews and Ferguson 2015).

The baleen plates of mature bowhead whales can measure up to four meters long, which, at an annual growth rate of approximately $17-18 \mathrm{~cm}$ per year, contain approximately 20-25 years of growth (Lubetkin et al. 2008). Keratinous (spring) and dashed black arrows broad southward migration (fall). Map after COSEWIC (2009), Dueck and Ferguson (2009), Quakenbush et al. (2013), and Harwood et al. (2017). (Color figure online)

baleen is metabolically inert and includes within it biogeochemical markers such as stable isotopes (Schell et al. 1989a, b). Carbon $\left(\delta^{13} \mathrm{C}\right)$ and nitrogen $\left(\delta^{15} \mathrm{~N}\right)$ stable isotope ratios have been widely used to investigate trophic linkages, foraging ecology and the relative importance of feeding locations of migratory species (e.g., Hobson 1999; Newsome et al. 2010; Matthews and Ferguson 2015). The stable isotope approach is based on the principle that the isotopic composition of a consumer closely reflects the composition of its assimilated diet due to the predictable enrichment of the heavier isotope in consumer tissues during metabolic processes (DeNiro and Epstein 1981; Minagawa and Wada 1984). Nitrogen isotopes are commonly used to assess food web structure including the trophic position of species and patterns of accumulation of contaminants such as mercury $(\mathrm{Hg})$ in marine food webs (Atwell et al. 1998). $\delta^{13} \mathrm{C}$ is typically applied to distinguish isotopically distinct food webs, which allow tracing of energy flow and foraging habitat. For example, in the Beaufort-Chukchi Sea region, Dunton et al. (1985) discovered a longitudinal $\delta^{13} \mathrm{C}$ gradient in zooplankton, which are more ${ }^{13} \mathrm{C}$-depleted in the west, possibly due to large inputs of terrestrial carbon from the Mackenzie River (Saupe et al. 1989; Schell et al. 1998). This $\delta^{13} \mathrm{C}$ gradient appears to be a robust and persistent feature spanning the migratory route of the western bowhead whales (e.g., Pomerleau et al. 2014b, 2016). A west to east decline in $\delta^{13} \mathrm{C}$ has not been found in the Canadian Arctic Archipelago, 
and regional $\delta^{13} \mathrm{C}$ variation in zooplankton in the Eastern Canadian Arctic is less pronounced (Pomerleau et al. 2011b, 2016).

Previous studies have shown that stable isotope ratios along baleen plates provide insight into seasonal movements between feeding grounds (Schell et al. 1989a, b; Hobson and Schell 1998; Caraveo-Patiño et al. 2007; Bentaleb et al. 2011; Ryan et al. 2013; Eisenmann et al. 2016). For instance, the seasonal shift in stable isotope values evident in Southern right whale (Eubalaena australis) baleen indicates an annual migration over the south Atlantic convergence (Best and Schell 1996). Hobson and Schell (1998) found no evidence of $\delta^{13} \mathrm{C}$ oscillations in bowhead whale baleen from three whales of the EC-WG population but found $\delta^{15} \mathrm{~N}$ oscillations which they thought could possibly be related to annual migrations. Recently, Matthews and Ferguson (2015) analyzed 14 plates and found synchronous cycles in both $\delta^{15} \mathrm{~N}$ and $\delta^{13} \mathrm{C}$ along the baleen plates of bowhead whales from the EC-WG population, which they linked to movements between isotopically distinct summer and winter habitats.

Mercury $(\mathrm{Hg})$ is a persistent and global pollutant (Dietz et al. 2011; Pacyna et al. 2016) that also deposits in whale baleen (Hobson et al. 2004). Mercury enters the Arctic via several pathways (i.e., atmospheric deposition, riverine transport, ocean currents), which are influenced by various environmental factors including climate variability and seaice processes (Stern et al. 2012). To date, few studies have measured $\mathrm{Hg}$ and stable isotopes concurrently in baleen plates to investigate whether foraging occurs year-round. A recent study by Pomerleau et al. (2016) found large pan-Arctic regional variations in $\mathrm{Hg}$ concentrations at the base of the food chain that were related to regional ecosystem features, such as varying water masses and freshwater inputs, and highlighted an increased exposure to $\mathrm{Hg}$ in the marine food chain of the southern Beaufort Sea. Analysis of individual bowhead whale baleen plates has the potential to provide a biogeochemical record of the whale dietary exposure to $\mathrm{Hg}$ throughout their geographical range.

In this study, we present total $\mathrm{Hg}$ concentrations and $\delta^{13} \mathrm{C}$ and $\delta^{15} \mathrm{~N}$ isotopic compositions along baleen plates taken from eight individual bowhead whales from the BCB and the EC-WG populations. We examine the biogeochemical profiles along the plates to assess relationships between properties within plates; regional differences between bowhead populations; and evidence for seasonal cycling reflecting foraging patterns. The main objective is to assess whether bowhead whales forage year-round, as proposed in recent studies (e.g., Schell and Saupe 1993; Matthews and Ferguson 2015)

\section{Materials and methods}

\section{Baleen collection and preparation}

Bowhead whale baleen plates $(n=8)$ were collected from four individuals from the BCB population (1988-1996) and from four individuals from the EC-WG population (1996-1998) (Fig. 1). BCB bowhead samples were composed of three males and one female harvested by the Alaskan Inupiat (Table 1). The samples from the EC-WG population, comprising two males, one female, and one individual of unknown sex, were harvested by Inuit hunters or recovered from carcasses found on land (Table 1). A detailed description of each embedded baleen plate extraction and preparation can be found in Schell et al. (1989a) and in Hobson and Schell (1998). Briefly, algae films and other debris were removed from 0.8- to 3-m-long baleen plates using steel wool and a 2:1 chloroform-methanol solvent. Using a measuring tape, each baleen plate was sampled at intervals of $2.5 \mathrm{~cm}$ from the base (newest) to the tip (oldest) of each
Table 1 Bowhead whale (Balaena mysticetus) baleen sample list

\begin{tabular}{cllllll}
\hline Whale ID & Location & Month/year & Cause of death & Sex & Body length (m) & $\begin{array}{l}\text { Baleen } \\
\text { length } \\
(\mathrm{m})\end{array}$ \\
\hline BCB & & & & & & \\
90B5 & Barrow (AK) & $05 / 1990$ & Hunt & Female & 15.9 & 2.79 \\
88 WW3 & Wainwright (AK) & $06 / 1988$ & Hunt & Male & 13.4 & 2.07 \\
88 B10 & Barrow (AK) & $09 / 1988$ & Hunt & Male & 15.1 & 3.02 \\
9601 & Shingle Point (CA) & $07 / 1996$ & Hunt & Male & 11.2 & 1.68 \\
EC-WG & & & & & & 2.84 \\
9602 & Repulse Bay (CA) & $08 / 1996$ & Hunt & Male & 14.9 & 0.78 \\
9603 & Cape Dorset (CA) & $08 / 1996$ & Unknown & Female & 8.9 & 2.50 \\
9801 & Pangnirtung (CA) & $07 / 1998$ & Hunt & Male & 12.8 & 0.85 \\
IB01 & Isabella Bay (CA) & Unknown & Unknown & NA & NA \\
\hline
\end{tabular}

$B C B$ Bering-Chukchi-Beaufort population, $E C-W G$ Eastern Canada-West Greenland population 
plate (see Fig. 2) using a high-speed flexible-shaft engraving device along the outside edge of the plate. This sampling interval provided sub-seasonal temporal resolution (Schell et al. 1989b).

\section{Stable isotope analysis}

Approximately $1.5-2.0 \mathrm{mg}$ of powdered baleen material was loaded into tin cups and combusted in an elemental analyzer at $1800{ }^{\circ} \mathrm{C}$. Bulk stable isotopes of $\delta^{13} \mathrm{C}$ and $\delta^{15} \mathrm{~N}$ (the latter was measured in the EC-WG plates and one $\mathrm{BCB}$ plate) were measured using a continuous-flow isotope ratio mass spectrometer (CFIRMS) at the University of Alaska Fairbanks Stable Isotope Facility. Stable isotope ratios are expressed in delta $(\delta)$ notation, the normalized ratio of an unknown sample to an internationally accepted standard $\left(\delta^{15} \mathrm{~N}\right.$ or $\delta^{13} \mathrm{C}=\left(\left(R_{\text {sample }}-R_{\text {standard }}\right) / R_{\text {standard }}\right) \times 1000$, where $R$ is ${ }^{15} \mathrm{~N} /{ }^{14} \mathrm{~N}$ or ${ }^{13} \mathrm{C} /{ }^{12} \mathrm{C}$ ). The standard was atmospheric $\mathrm{N}_{2}$ for $\delta^{15} \mathrm{~N}$ and VPDB for $\delta^{13} \mathrm{C}$. Analytical error based on replicate analyses of samples and laboratory reference materials was within $0.2 \%$ for $\delta^{13} \mathrm{C}$ and $\delta^{15} \mathrm{~N}$.

\section{Determination of total mercury $(\mathrm{Hg})$}

Dry samples of about $70 \pm 30 \mathrm{mg}$ were weighted precisely in Teflon containers, placed in an ultrasound bath for $15 \mathrm{~min}$ with $5 \mathrm{~mL}$ of diluted $\mathrm{HNO}_{3}(0.2 \mathrm{~N})$, rinsed with demineralized water, and sonicated again for $30 \mathrm{~min}$ in the same acidic solution. After rinsing, the samples were maintained in dilute $\mathrm{HNO}_{3}(0.2 \mathrm{~N})$ for $12 \mathrm{~h}$ and rinsed once more with water. The samples, which remained visually intact throughout the treatment, were then mineralized with $2 \mathrm{~mL}$ of concentrated ultra clean $\mathrm{HNO}_{3}$ on a block heater at $90{ }^{\circ} \mathrm{C}$ for $1 \mathrm{~h}$. Once cooled, the digestates were diluted by adding $25 \mathrm{~mL}$ of demineralized water. Note that the samples were not reweighed prior to the digestion step with concentrated $\mathrm{HNO}_{3}$ to avoid risk of contamination due to further manipulations.

The Hg concentrations were determined through external calibration by cold vapor atomic fluorescence spectrophotometry (CVAFS; Bloom and Fitzgerald 1988) using the equipment supplied by Tekran Instruments Corporation (Hg detector, Model 2500). The analysis proceeded in three steps: (i) the reduction of $\mathrm{Hg}(\mathrm{II})$ to volatile $\mathrm{Hg}(0)$ with $\mathrm{SnCl}_{2}$, (ii) the pre-concentration of the produced $\mathrm{Hg}(0)$ by amalgamation on gold-coated sand, and (iii) the subsequent detection of the $\mathrm{Hg}$ thermally desorbed from the gold trap. Saturated $\mathrm{Hg}$ vapor was used for the calibration (Dumarey et al. 2010): a drop of $\mathrm{Hg}$ in was placed in an isolated bottle from which precise volumes (5-25 $\mu \mathrm{L}$ ) of air containing $\mathrm{Hg}$ at saturation were removed with a gas-tight syringe as the temperature was noted. The concentration of saturated $\mathrm{Hg}$ vapor in air $\left(\mathrm{Hg}_{\mathrm{V}}\right)$ expressed in amol $\left(10^{-18} \mathrm{~mol}\right)$ per liter $\left(\mathrm{L}^{-1}\right)$ at a given temperature $\left(T\right.$ (expressed in $\left.\left.{ }^{\circ} \mathrm{K}\right)\right)$ was determined with $\mathrm{Hg}_{\mathrm{V}}=\mathrm{A} \mathrm{e}^{\mathrm{BT}}$ (Beaudin et al. 2010), where $A$ is 2.5456 amol $\mathrm{L}^{-1}$ and $B$ is $0.082 \mathrm{~T}^{-1}$. From this
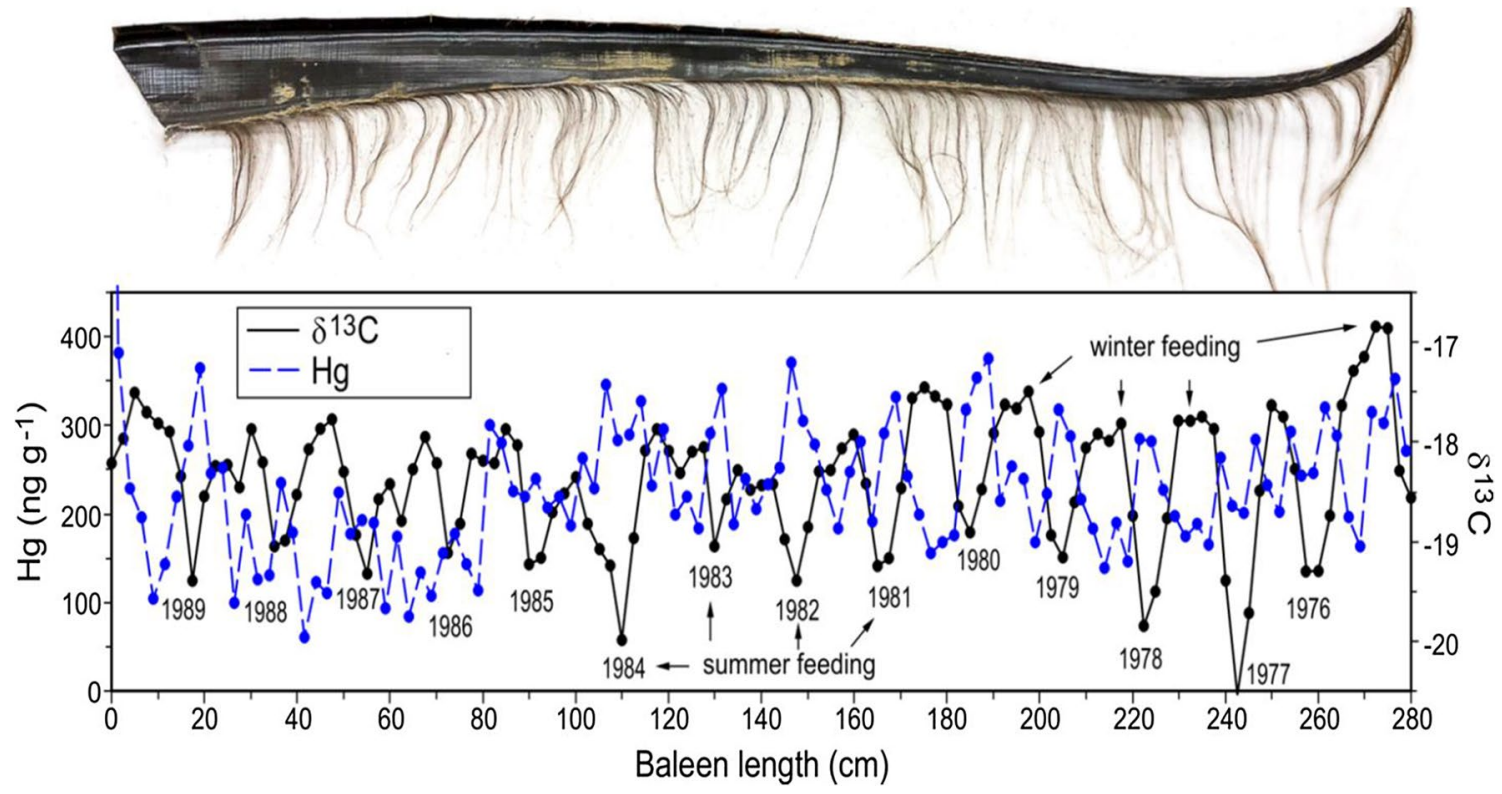

Fig. 2 A schematic diagram showing a representative baleen plate (top) and the record produced for $\delta^{13} \mathrm{C}$ and mercury $(\mathrm{Hg})$ by removing samples at intervals along the length of the baleen (bottom). The left (jaw) end of the baleen represents growth during the period just before the whale was caught. This record, which was obtained from a bowhead whale (Balaena mysticetus) from the BCB population, shows low $\delta^{13} \mathrm{C}$ values reflecting summer feeding in the Beaufort Sea and higher $\delta^{13} \mathrm{C}$ values reflecting winter feeding in the Bering Sea. The plate contains a record extending $\sim 15$ years preceding capture. Photo credit: DFO 
empirical equation, it can be calculated, for example, that $\mathrm{Hg}_{\mathrm{V}}$ is $0.6921 \times 10^{11}$ amol L${ }^{-1}$ (or $13.8 \mathrm{ng} \mathrm{mL}^{-1}$ ) at $293{ }^{\circ} \mathrm{K}$. The $\mathrm{Hg}$ concentration thus estimated is $4.2 \%$ lower than that calculated (14.4 $\mathrm{ng} \mathrm{mL}^{-1}$ ) for the same temperature using a slightly different equation recently proposed by Quetel et al. (2016). It is also close to the value $\left(13.0 \mathrm{ng} \mathrm{mL}^{-1}\right)$ that can be obtained from the previous relationship proposed by Dumarey et al. (2010).

The precision and accuracy of our analyses were assessed by replicate analyses of human hair certified reference material GBW 09101 from the Shanghai Institute of Nuclear Research Academia Sinica. Subsamples of this material were digested in the same manner as the baleen samples using concentrated $\mathrm{HNO}_{3}$. For $n=20$ analyses over a 1-month period, we report an average $\mathrm{Hg}$ concentration of $2.13 \pm 0.16 \mu \mathrm{g} \mathrm{g}^{-1}( \pm \mathrm{SD})$ compared to the certified value of $2.16 \mu \mathrm{g} \mathrm{g}^{-1}$. Our analytical precision and accuracy are thus estimated to be 7.5 and $1.4 \%$, respectively.

\section{Data analysis}

Bowhead baleen grows at an approximately constant rate for individuals with a body length $\geq 12 \mathrm{~m}$ (Lubetkin et al. 2008). For the baleen taken from whales near or larger than $12 \mathrm{~m}$ (Table 1), the stable isotope and $\mathrm{Hg}$ profiles were analyzed as time series assuming that baleen growth rates were constant.

The series of measurements along the plates were first detrended using a Gaussian low pass filter (Park and Gambéroni 1995; Klvana et al. 2004) to extract short-term trends (e.g., seasonal cycling). Cycles in each variable within individual plates were examined using autocorrelation functions, and period lengths were estimated from peak spectral frequencies of high-order autoregressive (AR) models fitted to detrended profiles (Shumway and Stoffer 2011). Cross-correlation functions (CCF) were used to assess relationships between each combination of variables $\left(\mathrm{Hg}, \delta^{13} \mathrm{C}, \delta^{15} \mathrm{~N}\right)$ across each individual plate. Analyses were conducted using the base functions and TSA package (Chan and Ripley 2012) in the statistical software R (R Core Team 2015).

\section{Results}

In general, baleen from whales in the BCB population had higher mean $[\mathrm{Hg}]\left(250.9 \pm 120.1 \mathrm{ng} \mathrm{g}^{-1}(\mathrm{sd})\right)$ in comparison to the EC-WG population (141.4 $\pm 77.3 \mathrm{ng} \mathrm{g}^{-1}$ ) (Fig. 3). Among all 378 baleen subsamples from the BCB population, $[\mathrm{Hg}]$ ranged from 32.5 to $593.7 \mathrm{ng} \mathrm{g}^{-1}, \delta^{13} \mathrm{C}$ from -23.5 to $-16.9 \%$ and $\delta^{15} \mathrm{~N}$ from 12.7 to $16.0 \%$ (Fig. 3). The 277 baleen subsamples from the $\mathrm{EC}-\mathrm{WG}$ population $[\mathrm{Hg}]$ ranged from 2.3 to $334.7 \mathrm{ng} \mathrm{g}^{-1}$, the $\delta^{13} \mathrm{C}$ from -19.6 to $-16.2 \%$ o and $\delta^{15} \mathrm{~N}$ from 11.5 to $15.2 \%$ (Fig. 3 ).
All BCB whale baleen plates had $\mathrm{Hg}$ and $\delta^{13} \mathrm{C}$ cycles, and $\delta^{15} \mathrm{~N}$ also cycled in the one plate for which it was measured (Fig. 4). Two main periods in the $\delta^{13} \mathrm{C}$ records were detected in the four BCB whales: one shorter period of 5.9-9.3 cm in length and a longer period of $16.9-21.0 \mathrm{~cm} . \delta^{15} \mathrm{~N}$ also cycled in baleen from whale 9601, the only BCB plate for which it was measured, with an estimated period $(17.6 \mathrm{~cm})$ that was comparable to both the $\delta^{13} \mathrm{C}$ and $\mathrm{Hg}$ cycles along that same plate (18.8 and $18.2 \mathrm{~cm}$, respectively) (Table 2).

Similar to $\delta^{13} \mathrm{C}$, spectral frequencies of modeled $\mathrm{Hg}$ oscillations also exhibited two main periods in all four whales: a shorter one ranging from 6.0 to $7.4 \mathrm{~cm}$, and a longer period ranging from 15.5 to $18.5 \mathrm{~cm}$ (Table 2). The cross-correlation functions indicated that $\delta^{13} \mathrm{C}$ and $\mathrm{Hg}$ patterns along the baleen plates were largely synchronous and exhibited an inverse relationship between the two variables in all four baleen plates (Fig. 4).

All EC-WG whale baleen plates had $\mathrm{Hg}, \delta^{13} \mathrm{C}$, and $\delta^{15} \mathrm{~N}$ cycles along their lengths (Fig. 5). High-order autoregressive models, fit to three of four detrended $\delta^{13} \mathrm{C}$ profiles, revealed a longer period in the plate from whale $9801(21.0 \mathrm{~cm})$ and shorter periods for plates from whales 9602 and IB01 (13.4-14.1 cm) (Table 2). High-order autoregressive models fit to all four detrended $\delta^{15} \mathrm{~N}$ profiles revealed one main period $(14.0-16.0 \mathrm{~cm})$ (Table 2$)$.

High-order autoregressive models were fit to all four detrended $\mathrm{Hg}$ profiles, exhibiting two main periods: one ranging from 5.4 to $8.2 \mathrm{~cm}$ and a second one ranging from 10.0 to $14.1 \mathrm{~cm}$ (Table 2). A longer period was also found for plates from whales 9603 and 9801 (20.7 and $21.7 \mathrm{~cm}$, respectively). Strong positive cross-correlation functions were found between $\delta^{15} \mathrm{~N}$ and $\delta^{13} \mathrm{C}$ in two plates (9602 and 9801), together with an inverse relationship between $\mathrm{Hg}$ and both $\delta^{13} \mathrm{C}$ and $\delta^{15} \mathrm{~N}$ in one plate (9801) (Fig. 5).

\section{Discussion}

\section{Seasonal cycling: BCB and EC-WG individual whales}

The longer synchronous $\mathrm{Hg}$ and $\delta^{13} \mathrm{C}$ cycles identified in all $\mathrm{BCB}$ whales are approximately the same as annual baleen growth rates (Lubetkin et al. 2008), and are consistent with foraging and seasonal migration between isotopically distinct food webs, with low $\mathrm{Hg}$ levels and higher $\delta^{13} \mathrm{C}$ peaks in winter (Bering and Chukchi Seas) and higher $\mathrm{Hg}$ levels and $\delta^{13} \mathrm{C}$ troughs in summer (Eastern Beaufort Sea). Mercury uptake appears to be more important on summer feeding grounds where more elevated values have been detected, especially in individual whales from the BCB population. Only a handful of studies have been conducted on the seasonality of $\mathrm{Hg}$ in the polar environment. Recently, Nerentorp-Mastromonaco et al. (2016) found that average 
Fig. 3 Inter-individual variations in a mercury $(\mathrm{Hg}), \mathbf{b} \delta^{13} \mathrm{C}$ and $\mathbf{c} \delta^{15} \mathrm{~N}$ for 8 individual bowhead whales (Balaena mysticetus) from both populations (BCB left panel, EC-WG right panel). Each black line, white box, and whiskers outside the box represent the median, the lower/upper quartiles, and the minimum/maximum values, respectively. White dots represent outliers
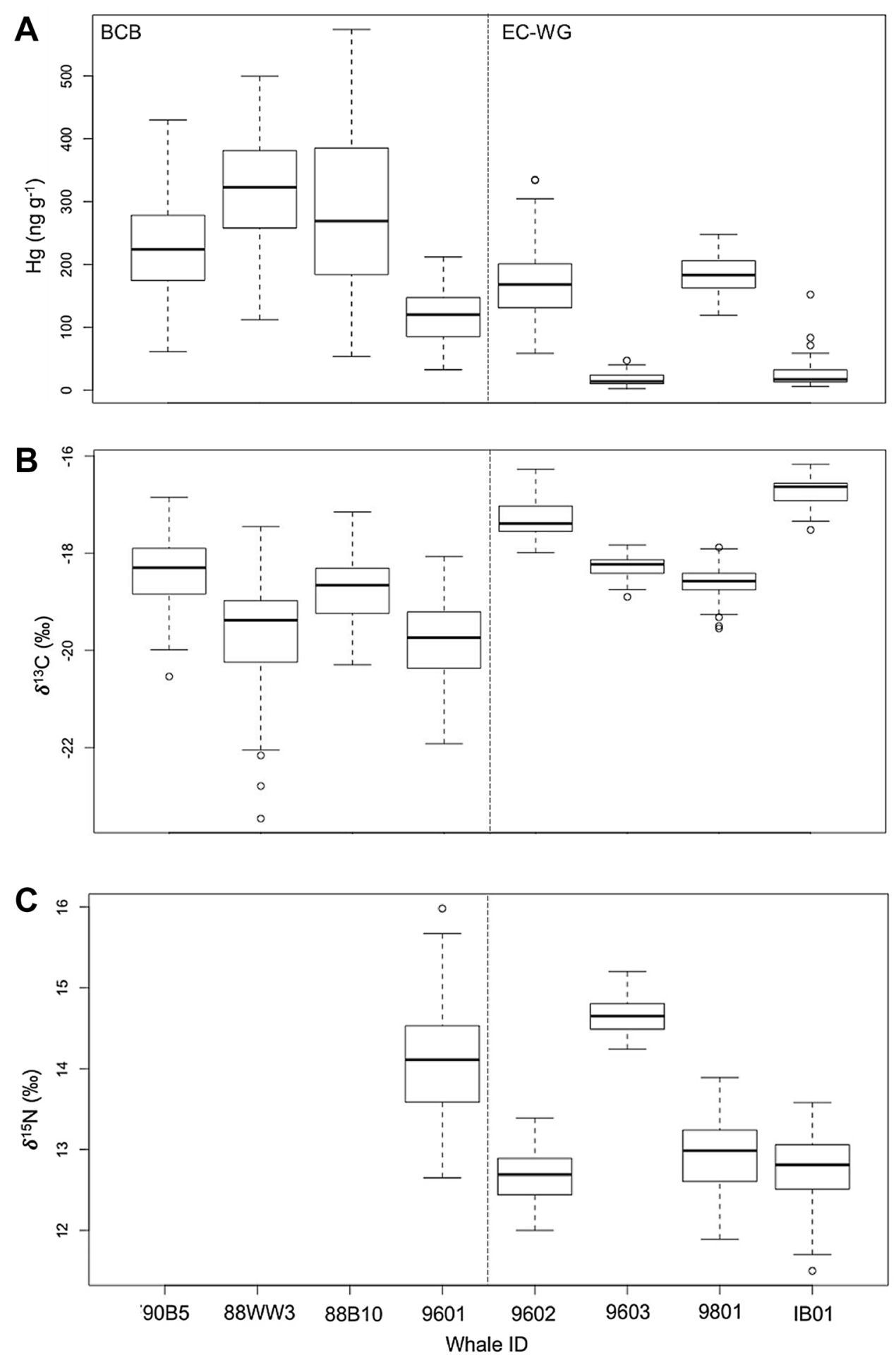

elemental $\mathrm{Hg}$ levels were lower in the environment (e.g., sea ice, snow, seawater) in winter while levels increased over spring and summer (e.g., after polar sunrise and the onset of mercury depletion events, see Stern and Macdonald 2005). They attributed this trend to multiple factors such as atmospheric deposition, temperature, and solar radiation. In the Canadian Beaufort Sea, calanoid copepods have been found to exhibit lower $\mathrm{Hg}$ concentrations during winter $\left(\sim 0.02\right.$ to $\left.0.06 \mu \mathrm{g} \mathrm{g}^{-1}\right)$ than during open-water season (0.04-0.127 $\mu \mathrm{g} \mathrm{g}^{-1}$ ) (Stern and Macdonald 2005; Loseto et al. 2008). However, it is important to note that the yearlong study conducted by Stern and Macdonald (2005) was part of the SHEBA drift program, which commenced in the Canada Basin/Beaufort Sea in October, 1997 and drifted 

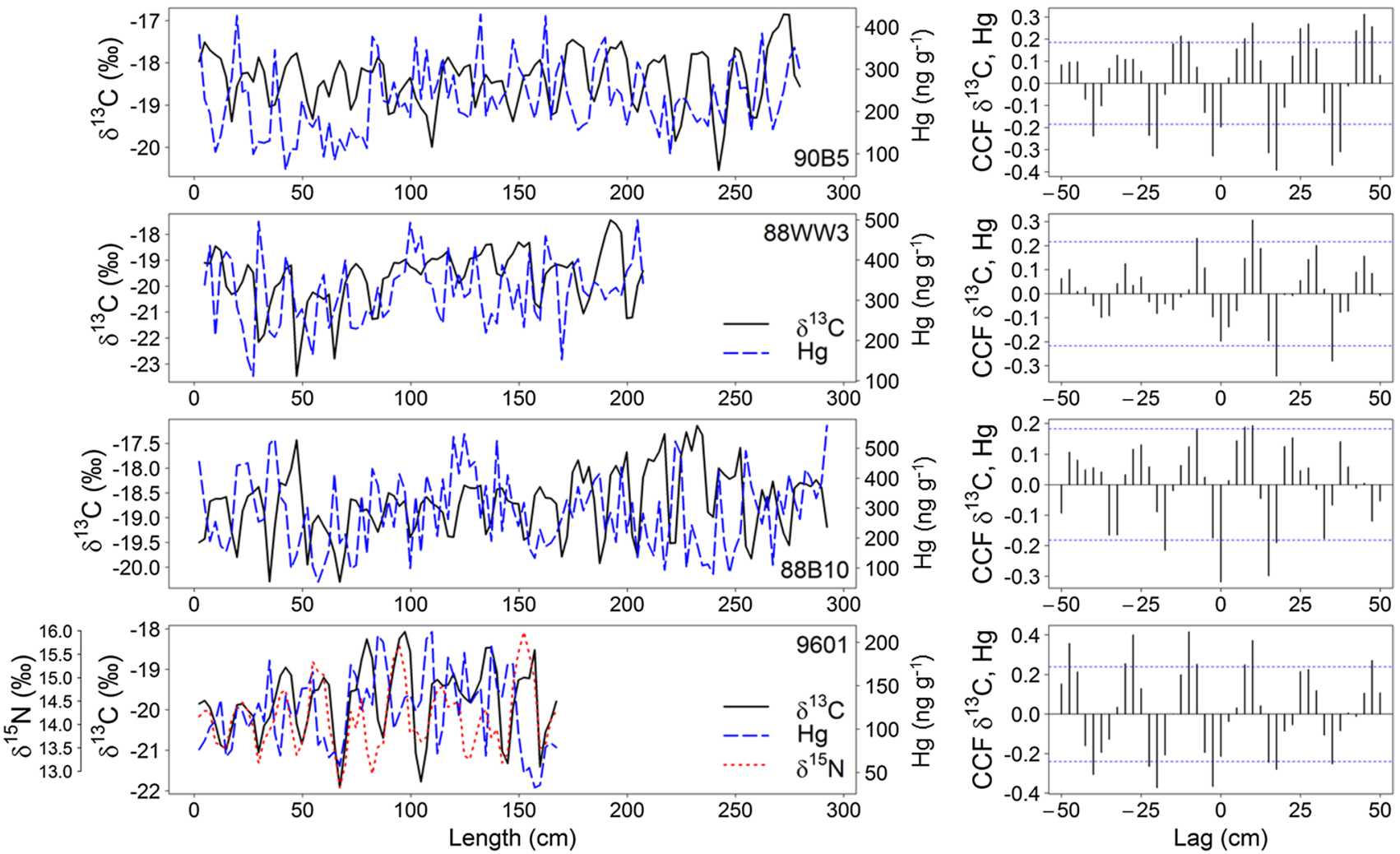

Fig. 4 Mercury $(\mathrm{Hg})$ and $\delta^{13} \mathrm{C}$ profiles (not detrended) along baleen plates, with sample cross-correlation functions (CCF) between detrended $\delta^{13} \mathrm{C}$ values and $\mathrm{Hg}$ in four Bering-Chukchi-Beaufort (BCB) bowhead whales (Balaena mysticetus). The CCF is the set of sample correlations between $\delta^{13} \mathrm{C}_{t+h}$ and $\mathrm{Hg}_{t}$, where $t=$ the same sample (lag 0) and $h= \pm 2.5 \mathrm{~cm}, \pm 5 \mathrm{~cm}, \pm 7.5 \mathrm{~cm}$, etc. Values falling outside the dotted lines (drawn at $1 / n \pm 2 / \sqrt{ } n$, where $n=$ series length) provide evidence of statistical significance at the $5 \%$ level. Negative correlations at 0 or lag $-2.5 \mathrm{~cm}$, with cycling apparent every 6-7 samples $(15-17.5 \mathrm{~cm})$, indicate an inverse relationship between $\delta^{13} \mathrm{C}$ and $\mathrm{Hg}$ cycles
Table 2 Periods of $\delta^{15} \mathrm{~N}, \delta^{13} \mathrm{C}$, and mercury $(\mathrm{Hg})$ cycles along baleen plates of Bering Chukchi Beaufort (BCB) and Eastern Canada-West Greenland (EC-WG) bowhead whales (Balaena mysticetus) esti- mated from spectra of autoregressive models (AR $(p)$, where $p$ is model order) fit to detrended data

\begin{tabular}{|c|c|c|c|c|c|c|c|}
\hline Population & Whale sample ID & $\delta^{15} \mathrm{~N}$ period $(\mathrm{cm})$ & Model order $(p)$ & $\delta^{13} \mathrm{C}$ period $(\mathrm{cm})$ & Model order $(p)$ & $\mathrm{Hg}$ period $(\mathrm{cm})$ & Model order $(p)$ \\
\hline \multirow[t]{4}{*}{$\mathrm{BCB}$} & 90B5 & Not measured & & $9.3,18.8$ & AR (16) & $6.0,17.0$ & AR (13) \\
\hline & 88WW3 & Not measured & & $5.9,8.8,19.4$ & AR (8) & $6.3,9.2,13.8,18.5$ & AR (17) \\
\hline & $88 \mathrm{~B} 10$ & Not measured & & $8.4,16.9$ & AR (12) & $6.3,15.5$ & AR (14) \\
\hline & 9601 & 17.6 & $\operatorname{AR}(9)$ & 18.8 & AR (14) & $7.4,11.2,18.2$ & AR (13) \\
\hline \multirow[t]{4}{*}{ EC-WG } & 9602 & $5.6,14.0,29.1$ & AR (14) & 14.1 & $\mathrm{AR}(11)$ & $5.4,14.1$ & AR (15) \\
\hline & 9603 & 16.0 & $\mathrm{AR}(3)$ & Not detected & & $6.3,10.0,20.7$ & $\mathrm{AR}(6)$ \\
\hline & 9801 & 21.7 & $\mathrm{AR}(7)$ & 21.0 & $\operatorname{AR}(7)$ & $8.2,12.9,21.7$ & $\mathrm{AR}(9)$ \\
\hline & IB01 & $8.2,14.1$ & $\mathrm{AR}(5)$ & $6.3,13.4$ & AR (4) & $5.5,10.5$ & AR (8) \\
\hline
\end{tabular}

westward to eventually reach the Chukchi Abyssal Plain and Mendeleev Basin in October, 1998. On examining their THg and $\mathrm{MMHg}$ data in the context of the oceanographic features along the drift track, Stern and Macdonald concluded that variation in zooplankton $\mathrm{Hg}$ concentration along the track primarily reflected ocean structure; Beaufort Sea/Canada
Basin samples were approximately twofold higher in $\mathrm{Hg}$ than Chukchi Sea samples.

In a more recent paper, Loseto et al. (2015) examined data for western beluga (Delphinapterus leucas) populations, which, like bowhead whales, migrate annually between the Bering and Beaufort Seas. After removing the effects of 

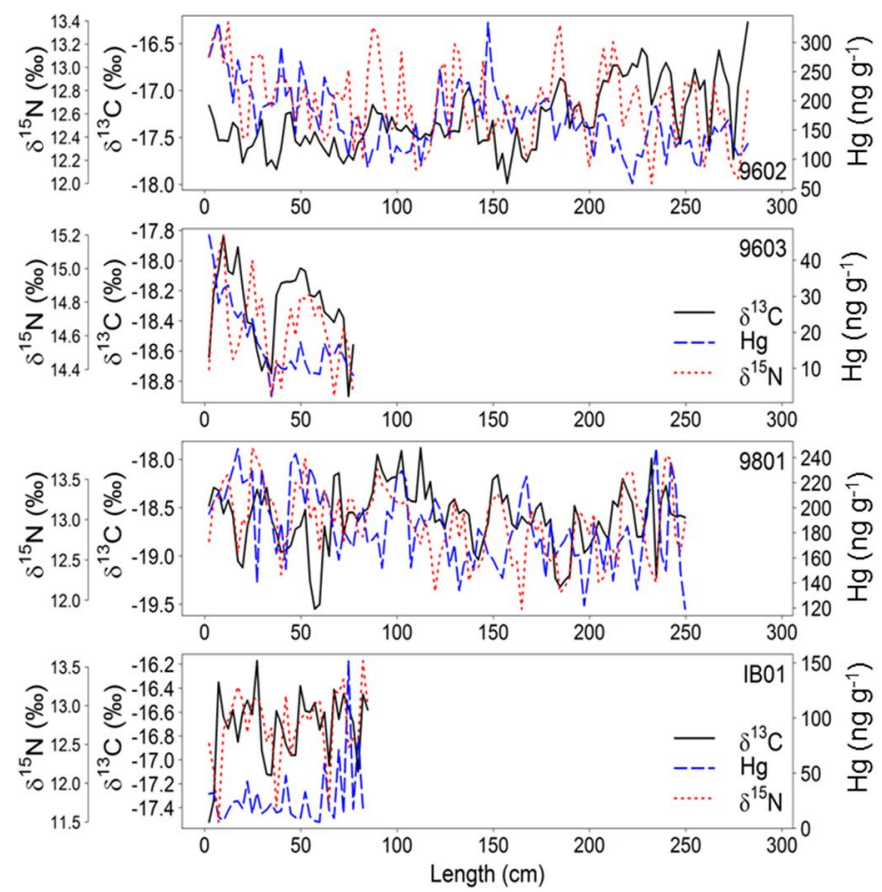

Fig. 5 Mercury ( $\mathrm{Hg}), \delta^{13} \mathrm{C}$, and $\delta^{15} \mathrm{~N}$ profiles (not detrended) along baleen plates and sample cross-correlation functions (CCF) between detrended $\delta^{13} \mathrm{C}$ values and $\mathrm{Hg}$ and detrended $\delta^{13} \mathrm{C}$ and $\delta^{15} \mathrm{~N}$ values in four Eastern Canada-West Greenland (EC-WG) bowhead whales

age and dietary factors, Loseto et al. (2015) found residual trends in $\mathrm{Hg}$ with time that could not be explained by recent declines in anthropogenic $\mathrm{Hg}$ emissions. They concluded that the observed biogeographical differences in zooplankton $\mathrm{Hg}$ concentration coupled with decadal variation (e.g., Pacific Decadal Oscillation) offered a more plausible explanation. With respect to our bowhead baleen data, the pattern of higher $[\mathrm{Hg}] /$ lower $\delta^{13} \mathrm{C}$ when animals were foraging in the Beaufort Sea conforms to the dominant biogeographic distribution found by Stern and Macdonald (2005). Unlike the $\delta^{13} \mathrm{C}$ data base, we do not yet have sufficient temporal data for the Beaufort and Bering populations to say whether or not the large-scale $\mathrm{Hg}$ differences between these seas are perennial, but a long-standing puzzle has been the observation that western Arctic (Beaufort Sea) populations are more exposed to $\mathrm{Hg}$ than populations in the eastern Archipelago and Baffin Bay (Brown et al. 2018). This higher Hg exposure could be due to a number of factors including atmospheric deposition, or the intensity of $\mathrm{Hg}$ methylation within Beaufort Sea subsurface waters (e.g., see Wang et al. 2012).

The food web utilized by bowhead whales from the BCB population in summer is characterized by well-documented depletion in $\delta^{13} \mathrm{C}$ values (e.g., Dunton et al. 1985; Schell et al. 1989a, 1998; Stern and Macdonald 2005; Pomerleau et al. 2014b) that may possibly derive from the large amount of terrestrial/riverine dissolved organic carbon supplied by
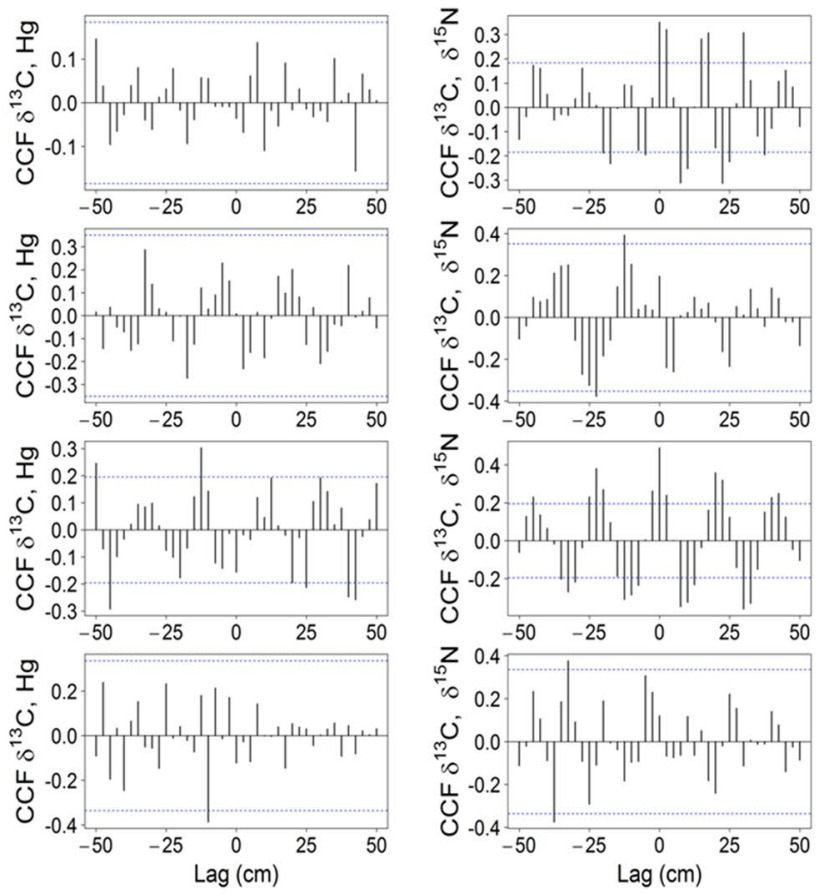

(Balaena mysticetus). See Fig. 4 legend for explanation of CCFs, which show a less obvious relationship between $\delta^{13} \mathrm{C}$ and $\mathrm{Hg}$ in $\mathrm{EC}-$ WG whales than BCB whales, but positive correlations between $\delta^{13} \mathrm{C}$ and $\delta^{15} \mathrm{~N}$ at or near lag 0 (indicating largely synchronized cycling)

the Mackenzie River and other smaller Arctic rivers (Gordeev et al. 1996; Lobbes et al. 2000). On the other hand, zooplankton isotopic signatures from the Bering Sea and Bering Strait areas are more ${ }^{13} \mathrm{C}$-enriched than those from the Eastern Beaufort Sea, as values increase along an east-to-west gradient (Dunton et al. 1985; Pomerleau et al. 2014b). Bowhead stomach content analysis (Sheffield and George 2009) found that winter feeding in the Bering Sea, especially near St. Lawrence Island, was significant given that over a third of the samples analyzed contained food (mainly copepods).

Similar to BCB bowhead whale baleen plates, the EC-WG plates exhibited $\mathrm{Hg}, \delta^{13} \mathrm{C}$, and $\delta^{15} \mathrm{~N}$ cycles consistent with annual baleen growth and reflecting seasonal foraging patterns. The synchronized cycles in all three variables were noted in the two whales with the longest plates, with peak values in isotopic ratios during summer feeding. Fasting physiology, at least as we understand it from studies of other animals in negative protein balance, cannot explain these nitrogen isotope trends. Animals deprived of enough protein to meet daily metabolic requirements display higher $\delta^{15} \mathrm{~N}$ values in their tissues, which is thought to reflect ${ }^{15} \mathrm{~N}$ enrichment as they catabolize endogenous protein stores. However, higher $\delta^{15} \mathrm{~N}$ values in the baleen of EC-WG whales occurred in the most recently grown baleen in summer, when they are known to feed heavily on zooplankton blooms. Recent studies such as Aguilar et al. (2014) and 
Matthews and Ferguson (2015) observed a similar pattern of ${ }^{15} \mathrm{~N}$ enrichment in summer in baleen plates of a larger sample of EC-WG bowhead whales and in fin whales (Balaenoptera physalus), respectively, that are also contrary to the proposal that fasting leads to higher $\delta^{15} \mathrm{~N}$ values (e.g., Best and Schell 1996; Cherel et al. 2005; Lee et al. 2012). It is more likely that summer feeding in regions with different baseline values or different types of prey led to depletion in ${ }^{15} \mathrm{~N}$ (e.g., Aguilar et al. 2014). The stable isotope ratios of bowhead whales' main zooplankton prey (e.g., Calanus spp.) are known to vary spatially and/or temporally within their Eastern Arctic range (Hobson et al. 2002; Pomerleau et al. 2011b). The seasonal cycling observed in the isotopic ratios of the baleen plates is probably related, in part, to the geographic variability in the isotopic signatures of zooplankton across the bowhead foraging domain. The welldescribed, perennial pattern of $\delta^{13} \mathrm{C}$ depletion from west to east in the western arctic has been observed in sediments, several taxa of zooplankton and has been clearly linked to bowheads migrating (and feeding) longitudinally across this region (e.g., Schell et al. 1989a; Stern and Macdonald 2005). Analyzing different whales from the ones used in our study, Matthews and Ferguson (2015) found the amplitudes of both $\delta^{13} \mathrm{C}$ and $\delta^{15} \mathrm{~N}$ along baleen of EC-WG whales were consistent with spatial differences in zooplankton across the region reported by Pomerleau et al. (2011b).

The records in the EC-WG whales were noisier making cycles less clear and likely reflecting more variable movement/migration patterns coupled with shorter distances and less isotopically distinct food webs. In the eastern Canadian Arctic, the paths of seasonal migrations and the locations of winter and summer grounds (Fig. 1) of EC-WG bowhead whales are more variable than for the $\mathrm{BCB}$ population. For instance, a portion of the EC-WG population, mainly large adult females, travel across Baffin Bay in late winter to forage along the coast of West Greenland in spring (Heide-Jørgensen et al. 2003; Laidre et al. 2007) while another segment of the population overwinter in Hudson Strait, northern Hudson Bay and/or Cumberland Sound (Finley 1990; Reeves and Mitchell 1990). Similarly, summer feeding locations are variable and comprise various fjords and bays in the Eastern Canadian Arctic (e.g., Cumberland Sound, Foxe Basin, Lancaster Sound, Admiralty Inlet and Hudson Bay) (Koski et al. 2006; Higdon and Ferguson 2010). Previous satellite telemetry studies have also shown large inter-individual variability in seasonal movement (Heide-Jørgensen et al. 2003).

\section{Mercury levels in BCB and EC-WG whales}

Our findings suggest that individual whales from the $\mathrm{BCB}$ population have a greater uptake of $\mathrm{Hg}$ on their summer feeding grounds. Several factors could contribute to the higher $\mathrm{Hg}$ concentrations observed in the western Arctic bowhead baleen plates, which also contained lower $\delta^{13} \mathrm{C}$ values. For example, the Mackenzie River, which supplies large amounts of terrigenous organic carbon with low $\delta^{13} \mathrm{C}$ is also known to supply $\mathrm{Hg}$ to the Eastern Beaufort Sea in summer (Leitch et al. 2007; Andersson et al. 2008; Emmerton et al. 2013). Although the underlying cause(s) remain unclear, it has long been observed that biota from the Canadian western Arctic exhibit higher $\mathrm{Hg}$ concentrations than their eastern Arctic counterparts (e.g., Braune et al. 2014). A recent study by Pomerleau et al. (2016) found increased exposure to $\mathrm{Hg}$ in the marine food chain of the southern Beaufort Sea together with more depleted $\delta^{13} \mathrm{C}$ in zooplankton (bowhead whales' prey) from that region compared to other pan-Arctic locations. High $\mathrm{Hg}$ concentrations have been found in the Beaufort Sea beluga whale population, which forages in that region during summer (Loseto et al. 2008, 2015). Furthermore, polar bears (Ursus maritimus) and ringed seals (Pusa hispida) also show higher $\mathrm{Hg}$ exposure in the Eastern Beaufort Sea compared to other Arctic regions (AMAP 2011).

Concentrations of $\mathrm{Hg}$ were lower for EC-WG individual plates compared to the BCB plates. In the Eastern Arctic, there is no known large primary source of $\mathrm{Hg}$ to the marine environment like the Mackenzie River in the Northwest Territories. However, $\mathrm{Hg}$ enters the Arctic via a range of processes including long-range atmospheric transport and deposition, coastal erosion and riverine transport and inflowing ocean currents (Macdonald et al. 2005; Stern et al. 2012). Kirk et al. (2012) suggested that the long-range transport of $\mathrm{Hg}$ from Asian countries represent a dominant source of atmospheric $\mathrm{Hg}$ to the Arctic. But it is important to note that differences in $\mathrm{Hg}$ methylating processes between ocean regions, associated with differences in respective carbon cycles, may be as important, or more important, in determining the concentrations of $\mathrm{Hg}$ accumulated by whales, than differences in the supply of $\mathrm{Hg}$ from atmospheric deposition or river inflow (Macdonald and Loseto 2010).

\section{Shorter periods: BCB and EC-WG individual whales}

The shorter $\mathrm{Hg}$ and $\delta^{13} \mathrm{C}$ cycles along the baleen plates of all whales in our study, spanning about half the annual growth, have not previously been described in the baleen of these populations (Fig. 1). These signals may reflect feeding in isotopically different regions while migrating during the spring and fall. Both the BCB and EC-WG populations migrate seasonally across their ranges between winter and summer grounds. As shown in Fig. 1, BCB bowhead whales generally travel north of their main wintering ground in the Bering Sea during the spring migration and usually pass northeast of Point Barrow along the Alaskan coast towards Canada from late April through June (Moore et al. 2010), although some whales have also been observed to travel up the northern coast of Chukotka in the spring (Citta et al. 
2012). In the fall, BCB bowheads migrate back to the Bering Sea by traveling along the Alaskan coast and southwest towards the Chukotka Peninsula (Harwood and Borstad 1985; Quakenbush et al. 2010). About a third of the bowhead whale stomach samples analyzed from spring harvest in Barrow were found to contain food (Lowry et al. 2004). Similarly, bowhead whales travel past Barrow again in the fall, from late September through October. Fall feeding in that region has also been documented through the analysis of stomach contents of freshly harvested whales and has been described as generally more intensive than feeding in the spring (Moore et al. 2010).

EC-WG bowhead whales are also known to use key feeding sites outside the main summer feeding season. Disko Bay, along the coast of West Greenland, is a well-known late winter-early spring feeding ground for bowhead whales foraging primarily on Calanus spp. (Laidre et al. 2007; Simon et al. 2009). In the Eastern Canadian Arctic, Finley (1990) suggested that a major part of the energetic requirement of EC-WG bowhead whales during the fall season derives from foraging on large concentrations of mature stage diapausing calanoid copepods in area such as Isabella Bay along the east coast of Baffin Island. Detailed analysis of $\mathrm{Hg}$ and SI spatial variation in these foraging areas relative to the summer and winter ranges would help to confirm our interpretation.

\section{Conclusion}

Using $\mathrm{Hg}$ in addition to $\delta^{13} \mathrm{C}$ and $\delta^{15} \mathrm{~N}$ measured along baleen plates, we found that individual whales from western and eastern populations feed year-round throughout their respective geographic ranges, but the nutritional contribution of winter foraging remains unclear. The previously unreported shorter periods of $\delta^{13} \mathrm{C}, \delta^{15} \mathrm{~N}$, and $\mathrm{Hg}$ suggest foraging in spring and fall, either along migration routes or in key areas where bowhead whales have been observed feeding in late fall. The seasonal pattern was stronger (clearer) in the BCB whale baleen. The EC-WG whale baleen exhibited more muted seasonal cycles, probably reflecting more variable migration routes and/or less contrast in foodweb properties between foraging locations.

The characterization of the $\mathrm{Hg}$ load in individual bowhead whales from 1960 to 1998 in our study can be compared with future studies to determine how or if mercury loadings to these animals are affected by climate change and the resulting increase in industrialization of the Arctic. Given the rate of change now occurring in Arctic seas, and especially in the nearshore habitats important to migratory species like bowhead whales, it seems all the more urgent to develop time series taking advantage of media like baleen, which have the potential to produce records of foraging and reproduction for individuals for periods spanning as much as 25 years (e.g., Hunt et al. 2014; Solazzo et al. 2017). Although complex, these records have the potential to reveal changes in food webs and consequent changes in whale foraging.

Acknowledgements This study was funded by Fisheries and Oceans Canada, U.S. Minerals Management Service and the Water Research Center, University of Alaska, Fairbanks. We thank the personnel of the Department of Wildlife Management, North Slope Borough, for obtaining the samples for this study and the cooperation of the Alaska Eskimo Whaling Commission. We are also grateful to DFO (L. Dueck and B. Dunn) and local hunters in Nunavut, Canada for the collection of baleen samples and to Luc Beaudin for technical assistance. We are deeply indebted to the late Dr. Don Schell who provided access to baleen collections and whose careful detective work provided us with the inspiration that we might be able to recover $\mathrm{Hg}$ records from these same plates that had been so instrumental in revising our understanding of bowhead biogeography.

\section{Compliance with ethical standards}

Human and animal rights Whales were harvested by Inuit beneficiaries as part of their land claims agreements whereby no animal care provisions are required. The authors have no commercial affiliations that would influence study design, data collection and analysis, decisions related to publishing, or in preparation of the manuscript. We did not receive funding from a commercial source.

\section{References}

Aguilar A, Giménez J, Gómez-Campos E, Cardona L, Borrell A (2014) $\delta 15 \mathrm{~N}$ value does not reflect fasting in mysticetes. PLoS ONE 9:e92288

AMAP (2011) AMAP assessment 2011: mercury in the arctic. Arctic Monitoring and Assessment Programme (AMAP), Oslo, p 193

Andersson ME, Sommar J, Gardfeldt K, Lindqvist O (2008) Enhanced concentrations of dissolved gaseous mercury in the surface waters of the Arctic Ocean. Mar Chem 110:190-194

Atwell L, Hobson KA, Welch HE (1998) Biomagnification and bioaccumulation of mercury in an arctic marine foodweb: insights from stable nitrogen isotope analysis. Can J Fish Aquat Sci 155:1114-1121

Beaudin L, Johannessen SC, Macdonald RW (2010) Coupling laser ablation and atomic fluorescence spectrophotometry: an example using mercury analysis of small sections of fish scales. Anal Chem 82:8785-8788

Bentaleb I, Martin C, Vrac M, Mate B, Mayzaud P, Siret D, de Stephains R, Guinet C (2011) Foraging ecology of Mediterranean fin whales in a changing environment elucidated by satellite tracking and baleen plate stable isotopes. Mar Ecol Prog Ser 438:285-302

Best PB, Schell DM (1996) Stable isotopes in southern right whale (Eubalaena australis) baleen as indicators of seasonal movements, feeding and growth. Mar Biol 124:483-494

Bloom N, Fitzgerald WF (1988) Determination of volatile mercury species at the picogram level by low-temperature gas-chromatography with cold-vapor atomic fluorescence detection. Anal Chim Acta 208:151-161

Braune B, Chételat J, Amyot M, Brown T, Claydon M, Evans M, Fisk A, Gaden A, Girard C, Hare A, Kirk J, Lehnherr I, Letcher R, Loseto LL, Macdonald RW, Mann E, McMeans B, Muir D, 
O’Driscoll N, Poulain A, Reimer K, Stern GA (2014) Mercury in the marine environment of the Canadian Arctic: review of recent findings. Sci Total Environ 509-510:67-90

Brown TM, Macdonald RW, Letcher RJ, Muir DCG (2018) The distribution and trends of persistent organic pollutants and mercury in marine mammals from Canada's Eastern Arctic. Sci Total Environ 618:500-517

Caraveo-Patiño J, Hobson KA, Soto LA (2007) Feeding ecology of gray whales inferred from stable-carbon and nitrogen isotopic analysis of baleen plates. Hydrobiologia 586:17-25

Chan KS, Ripley B (2012) TSA: time series analysis. R package version 1.01. http://CRAN.R-project.org/package=TSA

Cherel Y, Hobson KA, Bailleul F, Groscolas R (2005) Nutrition, physiology, and stable isotopes: new information from fasting and molting penguins. Ecology 86:2881-2888

Citta JJ, Quakenbush LT, George JC, Small RJ, Heide-Jorgensen MP, Bower H, Adams B, Brower L (2012) Winter movements of bowhead whales (Balaena mysticetus) in the Bering Sea. Arctic 65:13-34

Citta JJ, Quakenbush LT, Okkonen SR, Druckenmiller ML (2014) Ecological characteristics of core-use areas used by Bering-ChukchiBeaufort (BCB) bowhead whales, 2006-2012. Prog Oceanogr 136:201-222

Corkeron PJ, Connor RC (1999) Why do baleen whales migrate? Mar Mamm Sci 15:1228-1245

COSEWIC (2009) COSEWIC assessment and update status report on the Bowhead Whale Balaena mysticetus, Bering-Chukchi-Beaufort population and Eastern Canada-West Greenland population, in Canada. Committee on the Status of Endangered Wildlife in Canada. Ottawa. vii $+49 \mathrm{pp}$

DeNiro MJ, Epstein S (1981) Influence of diet on the distribution of nitrogen isotopes in animals. Geochim Cosmochim Acta 45:341-351

Dietz R, Basu N, Braune B, O'Hara T, Scheuhammer T (2011) What are the toxicological effects of mercury in arctic biota? AMAP Assessment 2011: mercury in the Arctic Monitoring and Assessment Programme (AMAP), Oslo, Norway, pp 113-137

Dueck L, Ferguson SH (2009) Habitat use by bowhead whales (Balaena mysticetus) of the Eastern Canadian Arctic. Canadian Science Advisory Secretariat Research Document 2008/082, Fisheries and Oceans Canada, Winnipeg, Manitoba

Dumarey R, Brown RJC, Corns WT, Brown AS, Stockwell PB (2010) Elemental mercury vapour in air: the origins and validation of the "Dumarey equation" describing the mass concentration at saturation. Accredit Qual Assur 15:409-414

Dunton KH, Saupe SM, Golikov AN (1985) Trophic relationships and isotopic gradients among arctic and subarctic marine fauna. Mar Ecol Prog Ser 56:89-97

Eisenmann P, Fry B, Holyoake C, Coughran D, Nicol S, Nash SB (2016) Isotopic evidence of a wide spectrum of feeding strategies in Southern Hemisphere humpback whale baleen records. PLoS ONE 11(5): 0156698

Emmerton CA, Graydon JA, Gareis JAL, St. Louis VL, Lesack LFW, Banack JKA, Hicks F, Nafziger J (2013) Mercury export to the Arctic Ocean from the Mackenzie River, Canada. Environ Sci Technol 47:7644-7654

Ferguson SH, Dueck L, Loseto LL, Luque SP (2010) Bowhead whale (Balaena mysticetus) seasonal selection of sea ice. Mar Ecol Prog Ser 411:285-297

Finley KJ (1990) Isabella Bay, Baffin Island: an important historical and present-day concentration area for the endangered bowhead whale (Balaena mysticetus) of the Eastern Canadian Arctic. Arctic 43:137-152

Finley KJ (2001) Natural history and conservation of the Greenland whale, or bowhead, in the northwest Atlantic. Arctic 54:55-76
Gordeev VV, Martin JM, Sidorov IS, Sidorova MN (1996) A reassessment of the Eurasian river input of water sediment, major elements and nutrients to the Arctic Ocean. Am J Sci 296:664-691

Harwood LA, Borstad GA (1985) Bowhead whale monitoring study in the southeast Beaufort Sea, July-September 1984. Environmental Studies Revolving Funds Report No. 009, Dept. of Indian and Northern Affairs, Ottawa, Ontario, Canada

Harwood LA, Quakenbush LT, Small RJ, George JG, Pokiak J, Pokiak C, Heide-Jorgensen MP, Lea EV, Brower H (2017) Movements and inferred foraging by bowhead whales in the Canadian Beaufort Sea during August and September 2006-12. Arctic 70:161-176

Heide-Jørgensen MP, Laidre KL, Wig O, Jensen MV (2003) From Greenland to Canada in ten days: tracks of bowhead whales across Baffin Bay. Arctic 56:21-31

Heide-Jørgensen MP, Laidre KL, Borchers D, Samarra F, Stern H (2007) Increasing abundance of bowhead whales in West Greenland. Biol Lett 3:577-580

Higdon JW, Ferguson SH (2010) Past, present, and future for bowhead whales (Balaena mysticetus) in northwest Hudson Bay. In: Ferguson SH, Loseto LL, Mallory ML (eds) A little less Arctic: top predators in the world's largest Northern Inland sea, Hudson Bay. Springer, Dordrecht, pp 159-177

Hobson KA (1999) Tracing origins and migration of wildlife using stable isotopes: a review. Oecologia 120:314-326

Hobson KA, Schell DM (1998) Stable carbon and nitrogen isotope patterns in baleen from eastern Arctic bowhead whales (Balaena mysticetus). Can J Fish Aquat Sci 55:2601-2607

Hobson KA, Fisk A, Karnovsky N, Holst M, Gagnon JM, Fortier M (2002) A stable isotope $(\delta 13 \mathrm{C}, \delta 15 \mathrm{~N})$ model for the North Water food web: implications for evaluating trophodynamics and the flow of energy and contaminants. Deep-Sea Res II 49:5131-5150

Hobson KA, Riget FF, Outridge PM, Dietz R, Born E (2004) Baleen as a biomonitor of mercury content and dietary history of North Atlantic minke whales (Balaenoptera acutorostrata): combining elemental and stable isotope approaches. Sci Total Environ 331:69-82

Hunt KE, Stimmelmayr R, George C, Hanns C, Suydam R, Brower H, Rolland RM (2014) Baleen hormones: a novel tool for retrospective assessment of stress and reproduction in bowhead whales (Balaena mysticetus). Cons Physiol 2(1):cou030

Kirk JL, Lehnherr I, Andersson M (2012) Mercury in arctic marine ecosystems: sources, pathways, and exposure. Environ Res 119:64-87

Klvana I, Berteaux D, Cazelles B (2004) Porcupine feeding scars and climatic data show ecosystem effects of the solar cycle. Am Nat 164:283-297

Koski WR, Heide-Jørgensen MP, Laidre KL (2006) Winter abundance of bowhead whales, Balaena mysticetus, in Hudson Strait, March 1981. J Cet Res Manage 8:39-144

Laidre KL, Heide-Jørgensen MP, Nielsen TG (2007) The role of the bowhead whale as a predator in West Greenland. Mar Ecol Prog Ser 346:285-297

Lee SH, Schell DM, McDonald TL, Richardson WJ (2005) Regional and seasonal feeding by bowhead whales Balaena mysticetus as indicated by stable isotope ratios. Mar Ecol Prog Ser 285:271-287

Lee TN, Buck CL, Barnes BM, O'Brien DM (2012) A test of alternative models for increased tissue nitrogen isotope ratios during fasting in hibernating arctic ground squirrels. J Exp Biol 215:3354-3361

Leitch DR, Carrie J, Lean D, Macdonald RW, Stern GA, Wang FY (2007) The delivery of mercury to the Beaufort Sea of the Arctic Ocean by the Mackenzie River. Sci Total Environ 373:178-195

Lobbes JM, Fitznar HP, Kattner G (2000) Biogeochemical characteristics of dissolved and particulate organic matter in Russian 
rivers entering the Arctic Ocean. Geochim Cosmochim Acta 64:2973-2983

Loseto LL, Stern GA, Deibel D, Connelly TL, Prokopowicz A, Lean DRS, Fortier L, Ferguson SH (2008) Linking mercury exposure to habitat and feeding behavior in Beaufort Sea beluga whales. J Mar Syst 74:1012-1024

Loseto LL, Stern GA, Macdonald RW (2015) Distant drivers or local signals: where do mercury trends in western Arctic belugas originate? Sci Total Environ 509-510:226-236

Lowry LF (1993) Food and feeding ecology. In: Burns JJ, Montague JJ, Bowles CJ (eds) The bowhead whale. Special Publication no. 2, Society for Marine Mammalogy, Lawrence, KS, pp 201-238

Lowry LF, Frost K (1984) Food and feeding of bowhead whales in western and northern Alaska. Sci Rep Whales Res Inst 35:1-16

Lowry LF, Sheffield G, George JG (2004) Bowhead whale feeding in the Alaskan Beaufort Sea, based on stomach contents analysis. J Cet Res Manage 6:215-223

Lubetkin SC, Zeh JE, Rosa C, George JC (2008) Age estimation for young bowhead whales (Balaena mysticetus) using annual baleen growth increments. Can J Zool 86:525-538

Macdonald RW, Loseto LL (2010) Are Arctic Ocean ecosystems exceptionally vulnerable to global emissions of mercury? A call for emphasized research on methylation and the consequences of climate change. Environ Chem 7:133-138

Macdonald RW, Harner T, Fyfe J (2005) Recent climate change in the Canadian Arctic and its impact on contaminant pathways and interpretation of temporal trend data. Sci Total Environ 342:5-86

Matthews CJD, Ferguson SH (2015) Seasonal foraging behaviour of Eastern Canada-West Greenland bowhead whales: an assessment of isotopic cycles along baleen. Mar Ecol Prog Ser 522:269-286

Minagawa M, Wada E (1984) Stepwise enrichment of $\delta^{15} \mathrm{~N}$ along food chains: further evidence and relation between $\delta^{15} \mathrm{~N}$ and animal age. Geochim Cosmochim Acta 48:1135-1140

Moore SE, Reeves RR (1993) Distribution and movement. In: Burns JJ, Montague JJ, Bowles CJ (eds) The bowhead whale. Spec. Publ. no. 2, Society for Marine Mammalogy, Lawrence, KS, pp 313-386

Moore SE, George CJ, Sheffield G, Bacon J, Ashjian C (2010) Bowhead whale distribution and feeding near Barrow, Alaska, in Late Summer 2005-06. Arctic 63:195-205

Nerentorp-Mastromonaco M, Gårdfeldt K, Jourdain B, Abrahamsson K, Granfors A, Ahnoff M, Dommergue A, Méjean G, Jacob HW (2016) Antarctic winter mercury and ozone depletion events over sea ice. Atmos Environ 129:125-132

Newsome SD, Clementz MT, Koch PL (2010) Using stable isotope biogeochemistry to study marine mammal ecology. Mar Mamm Sci 26:509-572

Pacyna JM, Travnikov O, De Simone F et al (2016) Current and future levels of mercury atmospheric pollution on a global scale. Atmos Chem Phys 16:12495-12511

Park YH, Gambéroni L (1995) Large-scale circulation and its variability in the south Indian Ocean from TOPEX/POSEIDON altimetry. J Geophys Res 100:24911-24929

Pomerleau C, Ferguson SH, Walkusz W (2011a) Stomach contents of bowhead whales (Balaena mysticetus) from four locations in the Canadian Arctic. Polar Biol 34:615-620

Pomerleau C, Winkler G, Sastri AR, Nelson RJ, Vagle S, Lesage V, Ferguson SH (2011b) Spatial patterns in zooplankton communities across the eastern Canadian sub-Arctic and Arctic waters: insights from stable carbon $\left(\delta^{13} \mathrm{C}\right)$ and nitrogen $\left(\delta^{15} \mathrm{~N}\right)$ isotope ratios. J Plank Res 33:1779-1792

Pomerleau C, Lesage V, Ferguson SH, Winkler G, Petersen SD, Higdon JW (2012) Prey assemblage isotopic variability as a tool for assessing diet and the spatial distribution of bowhead whale $\mathrm{Bal}$ aena mysticetus foraging in the Canadian eastern Arctic. Mar Ecol Prog Ser 469:61-174
Pomerleau C, Lesage V, Winkler G, Rosenberg B, Ferguson SH (2014a) Contemporary diet of bowhead whales (Balaena mysticetus) from the eastern Canadian Arctic inferred from fatty acid biomarkers. Arctic 67:84-92

Pomerleau C, Nelson RJ, Hunt BPV, Sastri AR, Williams WJ (2014b) Spatial patterns in zooplankton communities and stable isotope ratios $\left(\delta^{13} \mathrm{C}\right.$ and $\left.\delta^{15} \mathrm{~N}\right)$ in relation to oceanographic conditions in the sub-Arctic Pacific and western Arctic regions during the summer of 2008. J Plank Res 36:757-775

Pomerleau C, Stern GA, Pucko M, Foster KL, Macdonald RW, Fortier L (2016) Pan-Arctic concentrations of mercury and stable isotope ratios of carbon $\left(\delta^{13} \mathrm{C}\right)$ and nitrogen $\left(\delta^{15} \mathrm{~N}\right)$ in marine zooplankton. Sci Total Environ 551-552:92-100

Quakenbush LT, Citta JJ, George JC, Small RJ, Heide-Jørgensen MP (2010) Fall and winter movements of bowhead whales (Balaena mysticetus) in the Chukchi Sea and within a potential petroleum development area. Arctic 63:289-307

Quakenbush LT, Small RJ, Citta JJ (2013) Satellite tracking of bowhead whales: movements and analysis from 2006 to 2012. U.S. Dept. of the Interior, Bureau of Ocean Energy Management, Alaska Outer Continental Shelf Region, Anchorage, AK. OCS Study BOEM 2013-01110. 60 pp

Quetel CR, Zampella M, Brown RJC (2016) Temperature dependence of $\mathrm{Hg}$ vapour mass concentration at saturation in air: new SI traceable results between 15 and $30{ }^{\circ} \mathrm{C}$. Trends Anal Chem $85: 81-88$

R Core Team (2015) R: a language and environment for statistical computing. R Foundation for Statistical Computing, Vienna, Austria. http://www.R-project.org/

Reeves RR, Mitchell E (1990) Bowhead whales in Hudson Bay, Hudson Strait, and Foxe Basin: a review. Nat Can 117:25-43

Rugh D, DeMaster D, Rooney A, Breiwick J, Shelden K, Moore S (2003) A review of bowhead whale (Balaena mysticetus) stock identity. J Cet Res Manage 5:267-279

Ryan C, McHugh B, Trueman CN, Sabin R, Deaville R, Harrod C, Berrow SD, O'Connor I (2013) Stable isotope analysis of baleen reveals resource partitioning among sympatric rorquals and population structure in fin whales. Mar Ecol Prog Ser 479:251-261

Saupe SM, Schell DM, Griffiths W (1989) Carbon isotope ratio gradients in western Arctic zooplankton. Mar Biol 103:427-432

Schell DM, Saupe SM (1993) Feeding and growth as indicated by stable isotopes. In Burns JJ, Montague JJ, Cowles CJ (eds) The bowhead whale. Special publication No. 2 of the Society of Marine Mammalogy, pp 491-506

Schell DM, Saupe SM, Haubenstock N (1989a) Bowhead whale (Balaena mysticetus) growth and feeding as estimated by $\delta^{13} \mathrm{C}$ techniques. Mar Biol 103:433-443

Schell DM, Saupe SM, Haubenstock N (1989b) Natural isotope abundances in bowhead whale (Balaena mysticetus) baleen: markers of aging and habitat usage. Ecol Stud 68:260-269

Schell DM, Barnett BA, Vinette K (1998) Carbon and nitrogen isotope ratios in zooplankton of the Bering, Chukchi, and Beaufort Seas. Mar Ecol Prog Ser 162:11-23

Sheffield G, George JC (2009) Bowhead whale feeding in the northern Bering Sea near Saint Lawrence Island, Alaska. (Abstract) 18th Biennial Conference of the Biology of Marine Mammals, 12-16 October 2009, Quebec

Shumway RH, Stoffer DS (2011) Time series analysis and its applications: with R examples, 3rd edn. Springer, New York

Simon M, Johnson M, Tyack P, Madsen PT (2009) Behaviour and kinematics of continuous ram filtration in bowhead whales (Balaena mysticetus). Proc Biol Sci 276:3819-3828

Solazzo C, Fitzhugh W, Kaplan S, Potter C, Dyer KM (2017) Molecular markers in keratins from Mysticeti whales for species identification of baleen in museum and archaeological collections. PLoS ONE 12(8):e0183053 
Stern GA, Macdonald RW (2005) Biogeographic provinces of total and methyl mercury in zooplankton and fish from the Beaufort and Chukchi Seas: results from the SHEBA drift. Environ Sci Technol 39:4707-4713

Stern GA, Macdonald RW, Outridge PM, Wilson S, Chételat J, Cole A, Hintelmann H, Loseto LL, Steffen A, Wang F, Zdanowicz C
(2012) How does climate change influence Arctic mercury? Sci Total Environ 414:22-42

Wang F, Macdonald RW, Armstrong D, Stern GA (2012) Total and methylated mercury in the Beaufort Sea: the role of local and recent organic remineralization. Environ Sci Technol 46(21):11821-11828 